Original article

\title{
Synthesis of fluorescent ristocetin aglycon derivatives with remarkable antibacterial and antiviral activities
}

\author{
Attila Sipos ${ }^{\mathrm{a}, *}$, Gábor Máté ${ }^{\mathrm{a}}$, Erzsébet Rőth ${ }^{\mathrm{a}}$, Anikó Borbás ${ }^{\mathrm{a}}$, Gyula Batta $^{\mathrm{b}}$, Ilona Bereczki ${ }^{\mathrm{a}}$, Sándor Kéki ${ }^{\mathrm{c}}$, \\ István Jóna $^{\mathrm{d}}$, Eszter Ostorházi ${ }^{\mathrm{e}}$, Ferenc Rozgonyi ${ }^{\mathrm{e}}$, Evelien Vanderlinden ${ }^{\mathrm{f}}$, Lieve Naesens ${ }^{\mathrm{f}}$, \\ Pál Herczegh ${ }^{\mathrm{a}, *}$ \\ ${ }^{a}$ Department of Pharmaceutical Chemistry, Medical and Health Science Centre, University of Debrecen, Egyetem tér 1, H-4010 Debrecen, Hungary \\ ${ }^{\mathrm{b}}$ Department of Organic Chemistry, University of Debrecen, Egyetem tér 1, H-4010 Debrecen, Hungary \\ ${ }^{\mathrm{c}}$ Department of Applied Chemistry, University of Debrecen, Egyetem tér 1, H-4010 Debrecen, Hungary \\ ${ }^{\mathrm{d}}$ Department of Physiology, Medical and Health Science Centre, University of Debrecen, P. O. Box 22, Debrecen 4012, Hungary \\ e Microbiology Laboratory, Department of Dermatology, Venerology and Dermatooncology, Semmelweis University, Mária u. 41, H-1085 Budapest, Hungary \\ ${ }^{\mathrm{f}}$ Rega Institute for Medical Research, Katholieke Universiteit Leuven, B-3000 Leuven, Belgium
}

\section{A R T I C L E I N F O}

\section{Article history:}

Received 15 May 2012

Received in revised form

15 October 2012

Accepted 17 October 2012

Available online 25 October 2012

Dedicated to the memory of Prof. Ferenc

Sztaricskai who passed away on 23/03/2012.

\section{Keywords:}

Glycopeptide

Antiviral

Antibacterial

Aggregation

Multivalence

Fluorescence

\begin{abstract}
A B S T R A C T
Isoindole and benzoisoindole derivatives of ristocetin aglycon have been prepared by reaction with $o$-phthalaldehyde or naphthalene-2,3-dialdehyde and various thiols. The new compounds exhibited potent antibacterial and anti-influenza virus activity. The cluster forming and fluorescent properties of the aglycon derivatives were also studied.
\end{abstract}

(C) 2012 Published by Elsevier Masson SAS.

\section{Introduction}

Glycopeptide antibiotics vancomycin and teicoplanin are used for treating serious Gram-positive bacterial infections that are resistant to other antibiotics [1,2]. Due to the emergence and spread of glycopeptide-resistant enterococci (GRE) and glycopeptide intermediate-resistant Staphylococcus aureus (GISA), as well as teicoplanin-resistant Staphylococcus haemolyticus [3], there is an urgent need for new antibiotics active against resistant bacteria. Intensive research in this field was performed over the past 20 years [2].

Ristocetin A (1) is a glycopeptide-type antibiotic produced by Nocardia lurida [4]. This molecule contains six sugar moieties (two

\footnotetext{
* Corresponding authors. Tel.: +36 52512 900x22895; fax: +36 52512914.

E-mail addresses: sipos.attila@pharm.unideb.hu (A. Sipos), herczeghp@ gmail.com (P. Herczegh).
}

D-mannoses, D-glucose, D-arabinose, L-rhamnose and L-ristosamine) attached to the aglycon. In spite of its good antibacterial activity against Gram-positive strains, including methicillin-resistant $S$. aureus (MRSA) [5], this antibiotic has not been used in therapy, due to it's unwanted side-effect to cause aggregation of blood platelets [6]. Bardsley and co-workers recognized that the removal of the L-rhamnose moiety from ristocetin A eliminates this aggregating property [7]. In the framework of studies on synthetic modifications of aglycons of glycopeptide antibiotics, we anticipated that aglycoristocetin (2) could be a promising compound for obtaining new semisynthetic derivatives lacking the platelet aggregation property.

Since the important work of Nagarajan et al. [8], who was the first to report on lipophilic $\mathrm{N}$-alkyl derivatives of glycopeptide antibiotics with considerable activity against vancomycin-resistant bacteria, the concept of inserting lipophilic substituents led to several active antibiotics and the subclass of lipoglycopeptides (e.g. oritavancin, telavancin and dalbavancin) [9]. 


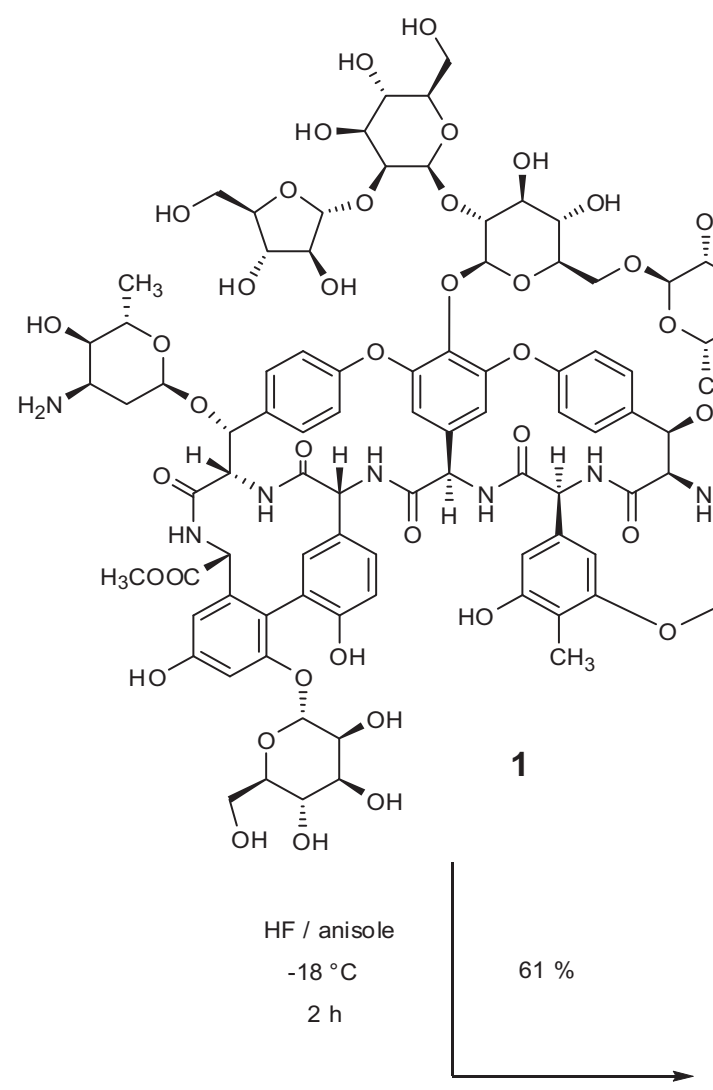

In the past few years, we have synthesized a series of new aglycoristocetin derivatives possessing not only high antibacterial activity but, in several cases, robust anti-influenza virus activity was noted [10-13]. On the basis of NMR and dynamic light scattering measurements, the antibacterial activity of some of our glycopeptide aglycon derivatives can be attributed to their multivalent interaction of their self-assembled aggregates with the bacterial cell wall peptidoglycan [13]. In order to study their mechanism of action in a cellular context (e.g. in influenza virus-infected cells), we were interested in synthesizing fluorescent aglycoristocetin derivatives. One of the well known methods for fluorescent tagging of amino acids is the preparation of their isoindole derivatives. Here we report the synthesis and physicochemical and biological evaluation of a series of such aglycoristocetin isoindole derivatives. In order to synthesize fluorescent aglycoristocetin derivatives with potentially interesting pharmacological properties, the widely used three-component isoindoleformation reaction [14] was chosen for the derivatization of the $\mathrm{N}$-terminal of this glycopeptide.

\section{Results and discussion}

\subsection{Chemistry}

The synthesis of the aimed compounds was started with the preparation of ristocetin aglycon (2) from the parent antibiotics using anhydrous hydrogen fluoride treatment (Scheme 1) according to Boger et al. [15].

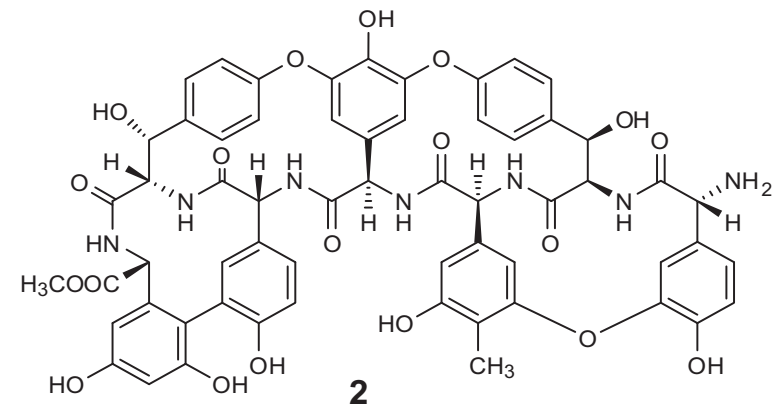

2

The formation of isoindole and benzoisoindole derivative in three-component reactions has been utilized extensively for fluorescent labelling of target molecules. The fluorogenic reaction involves the heteroring closing of $o$-phthalaldehyde (or its benzologs) with primary amine and a thiol (Scheme 2) and known for its relative robustness [16].

The investigation of the mechanism of reaction attracted considerable attention and it is widely agreed now that the multistep reaction [17] yields more stable isoindoles with bulky and lipophilic thiols. As it is usually recommended, reactions and isolation steps were performed with protection from light and products were stored in dark and at $0{ }^{\circ} \mathrm{C}$. Under these conditions we have not observed considerable decomposition during our investigations.

In addition to the previous consideration on the applied thiol reagent, the available structure-activity relationships were also reviewed to construct the more interesting aglycoristocetin derivatives. On one hand, it is known that the more lipophilic moieties inserted in the proximity of the $\mathrm{N}$-terminal resulted high antibacterial activities as it is discussed in references [11-13]. On the other hand, some S-glycosides were also applied in order to form products

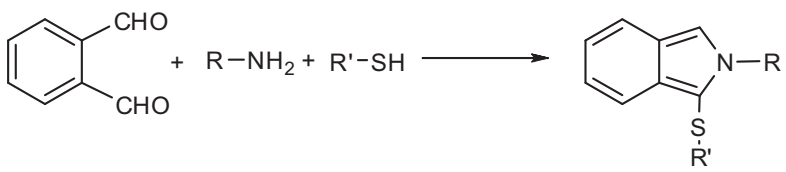

Scheme 2. General formation of 1,2-disubstituted isoindoles. 
Table 1

Formation of isoindole and benzoisoindole derivatives of aglycoristocetin 2 .<smiles>O=CC1CC[IH]CCC1C=[Rh]</smiles>

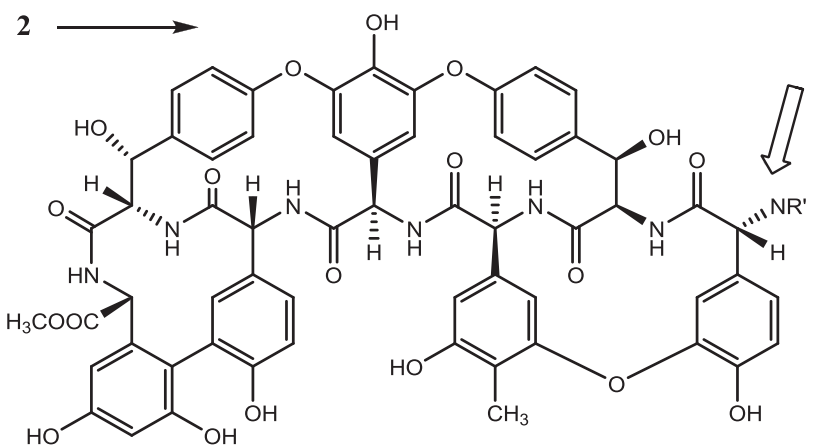

Product Starting dial

4<smiles>O=Cc1ccccc1C=O</smiles>

5<smiles>O=Cc1ccccc1C=O</smiles>

6<smiles>O=Cc1ccccc1C=O</smiles>

7<smiles>O=Cc1ccccc1C=O</smiles><smiles>Sc1nc2ccccc2s1</smiles><smiles>Sc1ncccn1</smiles><smiles>Sc1ccccc1</smiles>

9<smiles>O=Cc1cc2ccccc2cc1C=O</smiles><smiles>CC(=O)OCC1OC(Sc2c3ccccc3cn2C)OC(OC(C)=O)C1OC(C)=O</smiles><smiles>Cn1cc2ccccc2c1S[C@H]1O[C@H](CO)[C@@H](O)[C@H](O)[C@H]1O</smiles><smiles>Cn1cc2ccccc2c1Sc1ncccn1</smiles><smiles>Cn1cc2cc3ccccc3cc2c1Sc1ccccc1</smiles> 
Table 1 (continued)

\begin{tabular}{|c|c|c|c|c|c|}
\hline Product & Starting dialdehyde & Thiol reagent $(\mathrm{R}-\mathrm{SH})$ & Formed isoindole moiety $\left(\mathrm{R}^{\prime} \mathrm{N}-\right)^{\mathrm{a}}$ & Yields (\%) & $\log P^{b}$ \\
\hline 10 & & & & 19 & 5.70 \\
\hline
\end{tabular}

\footnotetext{
${ }^{\text {a }}$ General procedure: $0.11 \mathrm{mmol}$ dialdehyde, $0.11 \mathrm{mmol}$ thiol in $3 \mathrm{~mL} \mathrm{MeOH}$ (protected from light, under argon) stirred for $20 \mathrm{~min}$ at $0{ }^{\circ} \mathrm{C}$. $0.05 \mathrm{mmol} 2$ in $3 \mathrm{~mL} \mathrm{MeOH}$ added and stirred for $2 \mathrm{~h}$ at RT.

${ }^{b} \log P$ values were calculated with ChemSketch $\log P$ add-on [18].
}

with a chemical profile tending to the parent antibiotic $\mathbf{1}$. In Table 1 the structure of products and yields were concluded.

The structure of products 3-10 was confirmed by 2D NMR techniques, IR spectroscopy and MALDI-ToF measurements.

\subsection{Antibacterial studies}

The antibacterial activity of our products 3-10 was tested against a panel of strains of Gram-positive bacterial species (Table 2) using broth microdilution method as previously described [10]. Infections caused by some of these strains within the species are known to be susceptible to glycopeptide antibiotic therapy; however, this panel of bacteria includes such strains of the species too that are mainly responsible for nosocomial infections and resistant to glycopeptide agents.

Most of our derivatives were more active against this panel of bacteria than the reference glycopeptide antibiotics. Interestingly, the hardly accessible biofilm-forming Staphylococcus epidermidis was found to be more sensitive to derivative 3, $\mathbf{6}$ and $\mathbf{9}$ than to the reference antibiotics. In other words, these products can easily penetrate the outmost biofilm layer and inhibit peptidoglycan synthesis. Importantly, in case of Enterococcus faecalis possessing the vanA resistance gene compounds 3-10 exhibited remarkably lower inhibitory concentrations when compared to vancomycin and teicoplanin, two antibiotics currently used in the clinic. A similar observation was made with $E$. faecalis containing the van $B$ resistance gene, since compounds 3-10 were again much more active than vancomycin and derivatives $\mathbf{8}$ and $\mathbf{9}$ were as effective as the original teicoplanin. It can be concluded that lipophilicity of side-chains attached to the $N$-terminal of aglycon $\mathbf{2}$ was found to be favourable in the inhibition of tested strains in agreement with the results for compounds $\mathbf{7}-\mathbf{9}$.

\subsection{Antiviral activity}

It was reported by our groups that some lipophilic derivatives of aglycoristocetin are potently active against influenza $A$ and $B$ viruses [10-13]. The anti-influenza virus activity and cytotoxic concentrations of our products $\mathbf{3 - 1 0}$, in comparison to as well as three antiviral reference agents, are summarized in Table 3.

With the exception of compound $\mathbf{9}$, all the new aglycoristocetin derivatives showed considerable anti-influenza A virus activity. Compounds $\mathbf{6}$ and $\mathbf{7}$ were effective against influenza B virus as well. Several of our new compounds exerted their antiviral effect at remarkably lower concentrations than the clinically used reference agents. From a comparison of the antiviral $\mathrm{EC}_{50}$ values for compounds 3-10 with those of unsubstituted aglycoristocetin $\mathbf{2}$, it is evident that the newly formed 1,2-(benzo)isoindole moiety has a positive impact on anti-influenza virus activity. However, the (benzo)isoindole derivatized glycopeptides also had moderate cytotoxicity, since their MCC values were in the range of 6-20 $\mu \mathrm{M}$. In contrast, the parent aglycon 2 was not toxic at $100 \mu \mathrm{M}$ (the highest concentration tested). This cytotoxicity was even more pronounced for derivatives $\mathbf{3}$ and $\mathbf{1 0}$, which were the most active antiviral compounds in this series.

\subsection{Fluorescent activity}

An important reason for designing this set of new glycopeptides was to obtain derivatives with fluorescent activity. This property, together with high antibacterial activity, should offer an excellent opportunity for the study of physiological functions of bacteria at single-cell level [19]. In Table 4 the excitation and emission maxima of compounds 3-10 are shown, together with reference data for isoindole-labelled amino acids.

Our studies were started with the recording of UV-vis spectra in methanol, which confirmed that the aglycoristocetin $\mathbf{2}$ had no absorption at or above $300 \mathrm{~nm}$, while the characteristic absorption band was found to be in the region of $328-334 \mathrm{~nm}$ for the isoindole-derivatives and 340-341 $\mathrm{nm}$ for the benzoisoindolederivatives. These data served as starting points for recording the fluorescent spectra of compounds 3-10. Isoindole derivatives are often used for fluorescent-tagging of amino acids, therefore a comparison was made with some typical literature data [20]. The excitation maxima of our compounds 3-8 (for representative spectra see Fig. 1 Panel A) are very similar to these published data,

Table 2

Antibacterial activity of reference and newly synthesized glycopeptides 3-10.

\begin{tabular}{|c|c|c|c|c|c|c|c|c|c|c|c|}
\hline \multirow[t]{2}{*}{ Bacterium strains } & \multicolumn{11}{|l|}{$\mathrm{MIC}(\mu \mathrm{g} / \mathrm{mL})$} \\
\hline & Teicoplanin & Vancomycin & Ristocetin & 3 & 4 & 5 & 6 & 7 & 8 & 9 & 10 \\
\hline B. subtilis ATCC 6633 & 0.5 & 0.5 & 16 & 8 & 2 & 8 & 2 & 2 & 0.5 & 0.5 & 2 \\
\hline S. aureus MSSA ATCC 29213 & 0.5 & 0.5 & 128 & 2 & 1 & 4 & 1 & 1 & 1 & 0.5 & 2 \\
\hline S. aureus MRSA ATCC 33591 & 0.5 & 0.5 & 32 & 1 & 1 & 4 & 1 & 0.5 & 1 & 0.5 & 2 \\
\hline S epidermidis ATCC 35984 biofilm & 4 & 2 & 2 & 1 & 4 & 4 & 0.5 & 2 & 2 & 1 & 4 \\
\hline S. epidermidis mecA+ & 16 & 4 & 128 & 4 & 1 & 4 & 1 & 1 & 0.5 & 1 & 2 \\
\hline E. faecalis ATCC 29212 & 1 & 1 & 4 & 2 & 1 & 4 & 2 & 0.5 & 0.5 & 0.5 & 2 \\
\hline E. faecalis ATCC 15376 vanA+ & 256 & 256 & 16 & 8 & 1 & 4 & 4 & 1 & 0.5 & 0.5 & 2 \\
\hline E. faecalis ATCC 51299 vanB+ & 0.5 & 128 & 256 & 8 & 2 & 4 & 1 & 2 & 0.5 & 0.5 & 2 \\
\hline
\end{tabular}

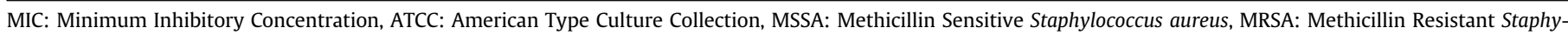
lococcus aureus, Biofilm: biofilm forming strain, $v a n A+$ : vanA gene positive, $v a n B+$ : vanB gene positive. 
Table 3

Anti-influenza virus activity and cytotoxicity of novel and reference compounds.

\begin{tabular}{|c|c|c|c|c|}
\hline \multirow[t]{2}{*}{ Compounds } & \multicolumn{3}{|l|}{$\mathrm{EC}_{50}(\mu \mathrm{M})$} & \multirow[t]{2}{*}{$\operatorname{MCC}(\mu \mathrm{M})$} \\
\hline & $\begin{array}{l}\text { Influenza } \\
\mathrm{A} / \mathrm{PR} / 8 / 34\end{array}$ & $\begin{array}{l}\text { Influenza } \\
\mathrm{A} / \mathrm{HK} / 7 / 87\end{array}$ & $\begin{array}{l}\text { Influenza } \\
\mathrm{B} / \mathrm{HK} / 5 / 72\end{array}$ & \\
\hline 3 & 0.16 & 0.072 & $>100$ & $\geq 4$ \\
\hline 4 & 0.27 & 2.3 & $>100$ & 20 \\
\hline 5 & 1.8 & 1.8 & $>100$ & 20 \\
\hline 6 & 0.67 & 0.68 & 1.4 & 6.4 \\
\hline 7 & 1.4 & 4.0 & 8.9 & 20 \\
\hline 8 & 0.30 & 1.8 & $>100$ & 20 \\
\hline 9 & $>100$ & $>100$ & $>100$ & 20 \\
\hline 10 & 0.08 & 0.36 & $>100$ & $\geq 0.8$ \\
\hline Aglycoristocetin & 2.3 & 6.8 & $>100$ & $>100$ \\
\hline Zanamivir & 0.3 & 1.8 & 34 & $>100$ \\
\hline Ribavirin & 6.8 & 8.9 & 8.9 & $\geq 20$ \\
\hline Amantadine & 7.6 & 2.3 & $>500$ & $>500$ \\
\hline
\end{tabular}

The experiments were performed in Madin Darby canine kidney cells. See reference [22] for a detailed description of the antiviral evaluation procedure.

$\mathrm{EC}_{50}$ : $50 \%$ effective concentration, or concentration producing $50 \%$ inhibition of virus-induced cytopathic effect, as determined by visual scoring of the CPE. MCC: Minimum compound concentration that causes a microscopically detectable alteration of normal cell morphology.

however the emission results show a considerable hypsochromic shift. The reason for this could be the difference in the secondary interactions between solvent and ligand molecules or between the glycopeptide part and the isoindole moiety. There is also a significant difference with the isoindole derivatives attached to carbohydrate substituents and heterocycles. The excitation spectra of benzoisoindole compounds 9-10 (for representative spectra see Fig. 1 Panel B) have typically a band with fine structure and, as a consequence of the extended $\pi$-electron structure, both the excitation and emission maxima have a bathochromic shift in comparison to the isoindole congeners.

\subsection{Aggregation study}

We examined the aggregation of compounds $\mathbf{6}$ and $\mathbf{9}$ in aqueous solutions containing small amount of DMSO for proper solubility, using dynamic light scattering measurements. This experiment showed the presence of aggregates with an effective diameter of more than $100 \mathrm{~nm}$ in monomodal distribution (Fig. 2).

These results pointed to a slight difference between 2-S-phenylisoindole derivative $\mathbf{6}$ and 2-S-phenyl-benzoisoindole $\mathbf{9}$, as compound $\mathbf{6}$ showed size distribution maximum at $160 \mathrm{~nm}$ while for compound $\mathbf{9}$ a $180 \mathrm{~nm}$ distribution maximum was observed. The aggregation-forming ability of the products is considered a direct consequence of the insertion of the new lipophilic moiety as it is confirmed by the $\log P$ values presented in Table 1 . In view of current progress in this field of research, multivalence is an important tool in the generation of more potent anti-infective agents [13].

Table 4

Excitation (ex) and emission (em) wavelength maxima for compounds 3-10.

\begin{tabular}{lll}
\hline Compounds & $\lambda_{\mathrm{ex}}(\mathrm{nm})$ & $\lambda_{\mathrm{em}}(\mathrm{nm})$ \\
\hline $\mathbf{3}$ & 333 & 397 \\
$\mathbf{4}$ & 334 & 406 \\
$\mathbf{5}$ & 334 & 394 \\
$\mathbf{6}$ & 337 & 423 \\
$\mathbf{7}$ & 338 & 424 \\
$\mathbf{8}$ & 370 & 417 \\
$\mathbf{9}$ & $340 ; 359 ; 375 ; 394^{\mathrm{a}}$ & 434 \\
$\mathbf{1 0}$ & $341 ; 361 ; 380^{\mathrm{a}}$ & 430 \\
Reference data for amino acids & 337 & 454 \\
$\quad$ with isoindoles &
\end{tabular}

${ }^{a}$ Fine structure with multiple maxima.

b Data obtained from Ref. [20].

\section{Conclusions}

Introduction of the isoindole and benzoisoindole moieties into the $\mathrm{N}$-terminal position of the aglycoristocetin molecule resulted in some compounds with pronounced antibacterial activity against a panel of bacteria including biofilm-forming and resistant strains.

We assume the self-assembly of the new compounds and the arising multivalent interaction of the aggregates with the repeating unit of the bacterial cell wall peptidoglycan to be a key-element in the mechanism of the antibacterial activity. The calculated $\log P$ values (Table 1) confirm the strong lipophilic effect of the newly formed moieties which directly contributes to aggregation. For some derivates the cluster formation has been proved by dynamic light scattering measurements. It is noteworthy, however, that some ristocetin aglycon derivatives having lipophilic side chains in the $N$-terminal position, prepared recently in this laboratory, turned out to be completely inactive against bacteria [13]. Therefore, the high antibacterial activity of the present series of ristocetin aglycon derivatives demonstrates the important contribution of the (benzo)isoindole moiety to the mechanism of action, independently of its lipophilic character. In addition, it does not seem to be direct correlation between the measure of lipophilicity $(\log P)$ and the biological activities of compounds 3-10. On the basis of the presented antibacterial test results the acetyl-protected glycosyl units (derivatives $\mathbf{3}$ and $\mathbf{5}$ ) are the less efficient thiyl substituents.

Similarly to our previous results $[10-13]$ the lipophilic modification of aglycoristocetin resulted in antibiotic derivatives with remarkable anti-influenza virus activity. Incorporation of isoindoles into the aglycoristocetin calls for high inhibitory activity against the tested influenza A strains almost in all cases (including glycosyl-thiyl substituted derivatives 3-5), and additionally two compounds (6 and 7) with strongly lipophilic character displayed outstanding anti-influenza B virus activity as well. Taking, however, the significantly different antiviral properties of the structurally resembling 6 and $\mathbf{9}$, it is hard to draw further conclusions for the structure-activity relationships.

Because of the promising antiviral and antibacterial activity of our (benzo)isoindole derivatives, further synthetic and biological studies are necessary on similar substrates to expand this field of knowledge and establish sound conclusions. This work is in progress.

\section{Experimental}

\subsection{General information}

The starting materials and solvents were purchased from commercial sources (Sigma-Aldrich or Fluka) and used as received. ${ }^{1} \mathrm{H}$ and ${ }^{13} \mathrm{C}$ NMR spectra were recorded at 500 and $125 \mathrm{MHz}$, respectively, with a Bruker DRX II 500 spectrometer at $300 \mathrm{~K}$, using $\mathrm{MeOH}-d_{4}$ as solvents and TMS (tetramethylsilane) as internal standard. Signal assignment was aided by 2D HSQC, COSY and TOCSY techniques of which exact parameters were performed in accordance of previously published methods [21]. The assignment of the substituted (benzo)isoindole moieties were performed on the basis of previously reported full assignation of compound 2 [21]. Mass spectra were recorded with Bruker Biflex-III MALDI TOF mass spectrometer. High-resolution mass spectral measurements were performed with a Bruker micrOTOF-Q instrument in the ESI mode. IR spectra were recorded on Perkin-Elmer 283 B spectrometer. The dynamic light scattering measurements were performed on Brookhaven Light Scattering device equipped with a BI-9000 digital correlator. Fluorescence measurements were performed in $1 \times 1 \mathrm{~cm}$ cuvettes in a SPEX Fluoromax single photon counting spectrometer (Jobin-Yvon, Spex Industries, Edison, NJ, U.S.A.). Data were collected at a rate of $1 \mathrm{~Hz}$ and stored digitally for later analysis. For 

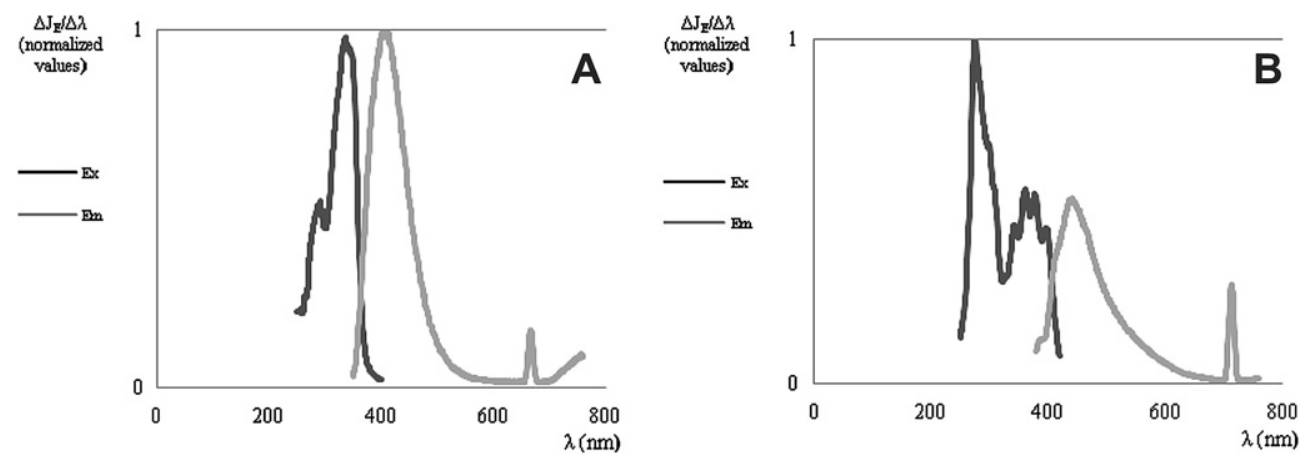

Fig. 1. The excitation and emission spectra of compounds 4 (Panel A) and 9 (Panel B).

purification of the products flash chromatography on Merck silica gel (Kieselgel 60), 0.040-0.063 mm (70-230 mesh) was used. Thin layer chromatography (TLC) was performed on Kieselgel $60 \mathrm{~F}_{254}$ (Merck). Spots were visualized by irradiation under UV lamp, and/or by spraying with an ammonium-molibdenate/sulfuric acid solution and heating, or using Pauly-reagent. Evaporations were carried out under diminished pressure at $35-40{ }^{\circ} \mathrm{C}$ (bath temperature). Investigation of the antibacterial activity of the antibiotics and their derivatives was carried out by measuring the MIC values as described earlier [21]. The cell-culture based assays to determine the inhibitory effect on influenza virus replication against, have been published elsewhere [22].

\subsection{General procedure}

Dialdehyde $(0.11 \mathrm{mmol})$ and thiol reagent $(0.11 \mathrm{mmol})$ were dissolved in $3.0 \mathrm{ml}$ of methanol in a flask protected from light and under argon atmosphere. The resulting solution was stirred at $0{ }^{\circ} \mathrm{C}$. A solution of $58 \mathrm{mg}$ aglycoristocetin $2(0.05 \mathrm{mmol})$ in $3.0 \mathrm{~mL}$ of methanol was added to this with constant argon gas flow and stirred for further $2 \mathrm{~h}$ at $0^{\circ} \mathrm{C}$. The reaction was followed by TLC with UV and Pauly detection. The product mixture was carefully evaporated under diminished pressure and purified with column chromatography. Yields were reported in Table 1.

\subsubsection{Product 3}

Off-white powder. TLC (DCM:MeOH = 95:5): 0.40. MALDI-TOF MS: $[\mathrm{M}+\mathrm{Na}]^{+}=1658.4 \mathrm{~m} / \mathrm{z}$, calculated for $\mathrm{C}_{82} \mathrm{H}_{73} \mathrm{~N}_{7} \mathrm{O}_{28} \mathrm{SNa}$ 1658.4; HRMS (ESI) $m / z$ found: $1636.4258\left[\mathrm{M}+\mathrm{H}^{+}\right.$, calculated: $1636.4297[\mathrm{M}+\mathrm{H}]^{+} ; \nu_{\max }(\mathrm{KBr}$ disc) 3394, 2925, 2854, 1749, 1662, $1595,1513,1213 ;{ }^{1} \mathrm{H}$ NMR $\left(\mathrm{MeOH}-d_{4}, 500 \mathrm{MHz}\right) \delta: 1.91,2.04,2.08$,
$2.15(4 \times \mathrm{OAc}), 3.81\left(\mathrm{COOCH}_{3}\right), 4.10,4.48,4.87,5.35,5.40,5.45,5.81$ (glycopeptides chiral CH), 4.85, 4.88, 5.13, 5.22, 5.42 (carbohydrate hydrogens), 7.32, 7.36, 7.45, 7.46, 7.48 (isoindole moiety). ${ }^{13} \mathrm{C}$ NMR $\left(\mathrm{MeOH}-d_{4}, 500 \mathrm{MHz}\right) \delta: 19.7$ (OAc), $23.3(\mathrm{OAc}), 52.4\left(\mathrm{COOCH}_{3}\right), 68.0$, 70.0, 72.7, 74.3 (carbohydrate carbons), 125.6, 131.3, 137.8, 138.1, 138.5 (isoindole moiety), 170.5, 171.0, 171.4, 171.6, 171.9, 172.2 (peptide carbonyls), $173.9\left(\mathrm{COOCH}_{3}\right)$.

\subsubsection{Product 4}

Off-white powder. TLC (DCM:MeOH = 8:2): 0.22. MALDI-TOF MS: $[\mathrm{M}+\mathrm{Na}]^{+}=1490.3 \mathrm{~m} / \mathrm{z}$, calculated for $\mathrm{C}_{74} \mathrm{H}_{65} \mathrm{~N}_{7} \mathrm{O}_{24} \mathrm{SNa}$ 1490.4; HRMS (ESI) $m / z$ found: $1468.3861[\mathrm{M}+\mathrm{H}]^{+}$, calculated: 1468.3874 $[\mathrm{M}+\mathrm{H}]^{+} ; \nu_{\max }(\mathrm{KBr}$ disc) 3418, 2928, 1654, 1516, 1210; ${ }^{1} \mathrm{H}$ NMR $\left(\mathrm{MeOH}-d_{4}, 500 \mathrm{MHz}\right) \delta: 3.38,3.41,3.48,3.64,3.75$ (carbohydrate hydrogens), $3.81\left(\mathrm{COOCH}_{3}\right), 4.14,4.51,4.88,5.33$, 5.40, 5.48, 5.80 (glycopeptides chiral $\mathrm{CH}$ ), $3.87\left(\mathrm{COOCH}_{3}\right), 7.30,7.33$, 7.40, 7.41, 7.48 (isoindole moiety). ${ }^{13} \mathrm{C} \mathrm{NMR}\left(\mathrm{MeOH}-d_{4}, 500 \mathrm{MHz}\right) \delta$ : $53.1\left(\mathrm{COOCH}_{3}\right), 58.0,63.2,71.4,73.1,82.3$ (carbohydrate $\mathrm{C}$ ), 124.7, 137.8, 138.1, 138.2, 138.4 (isoindole moiety), 170.7, 171.3, 171.4, 171.6, 171.9, 172.4 (peptide carbonyls), $173.4\left(\mathrm{COOCH}_{3}\right)$.

\subsubsection{Product 5}

Off-white powder. TLC (DCM:MeOH = 9:1): 0.25. MALDI-TOF MS: $[\mathrm{M}+\mathrm{Na}]^{+}=1657.6 \mathrm{~m} / \mathrm{z}$, calculated for $\mathrm{C}_{82} \mathrm{H}_{74} \mathrm{~N}_{8} \mathrm{O}_{27} \mathrm{SNa}$ 1657.7; HRMS (ESI) $m / z$ found: $1635.4462\left[\mathrm{M}+\mathrm{H}^{+}\right.$, calculated: $1635.4457[\mathrm{M}+\mathrm{H}]^{+} ; \nu_{\max }(\mathrm{KBr}$ disc $) 3435,1739,1649,1516,1210$ ${ }^{1} \mathrm{H}$ NMR $\left(\mathrm{MeOH}-d_{4}, 500 \mathrm{MHz}\right) \delta: 1.91,2.04,2.08,2.15$ (4 × OAc), 3.88 $\left(\mathrm{COOCH}_{3}\right), 3.81\left(\mathrm{COOCH}_{3}\right), 4.11,4.51,4.79,5.32,5.45,5.41,5.85$ (glycopeptides chiral $\mathrm{CH}$ ), 4.97, 5.09, 5.15, 5.38 (carbohydrate hydrogens), 7.29, 7.39, 7.44, 7.47, 7.49 (isoindole moiety). ${ }^{13} \mathrm{C}$ NMR $\left(\mathrm{MeOH}-d_{4}, 500 \mathrm{MHz}\right) \delta: 19.0(\mathrm{OAc}), 23.4(\mathrm{OAc}), 53.7\left(\mathrm{COOCH}_{3}\right), 68.4$,
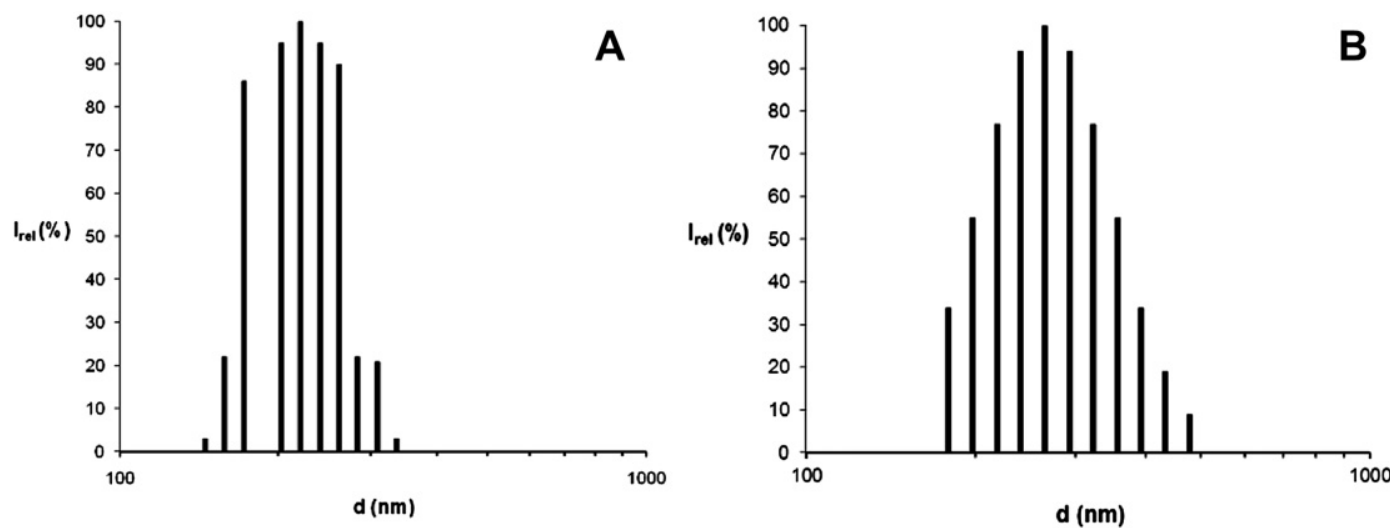

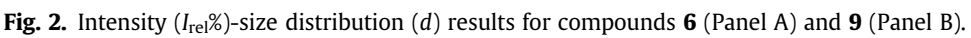


72.7 (carbohydrate C), 124.8, 138.0, 138.1, 138.5, 138.8 (isoindole moiety), 170.6, 171.0, 171.3, 171.4, 172.1, 172.4 (peptide carbonyls), $173.2\left(\mathrm{COOCH}_{3}\right)$.

\subsubsection{Product 6}

Off-white powder. TLC (DCM:MeOH = 9:1): 0.20. MALDI-TOF MS: $[\mathrm{M}+\mathrm{Na}]^{+}=1404.5 \mathrm{~m} / z$. calculated for $\mathrm{C}_{74} \mathrm{H}_{59} \mathrm{~N}_{7} \mathrm{O}_{19} \mathrm{SNa}$ 1404.7; HRMS (ESI) $m / z$ found: $1382.3658[\mathrm{M}+\mathrm{H}]^{+}$, calculated: 1382.3659 $[\mathrm{M}+\mathrm{H}]^{+}$; $\nu_{\max }(\mathrm{KBr}$ disc) $3420,2925,2853,1662,1513$, 1209; ${ }^{1} \mathrm{H}$ NMR $\left(\mathrm{MeOH}-d_{4}, 500 \mathrm{MHz}\right) \delta: 3.81\left(\mathrm{COOCH}_{3}\right), 3.81$ $\left(\mathrm{COOCH}_{3}\right), 4.12,4.50,4.84,5.40,5.44,5.47,5.80$ (glycopeptides chiral $\mathrm{CH}$ ), $6.95(\mathrm{Ph}-\mathrm{S}-), 7.18,7.49,7.50,7.51,7.55$ (isoindole moiety). ${ }^{13} \mathrm{C}$ NMR $\left(\mathrm{MeOH}-d_{4}, 500 \mathrm{MHz}\right) \delta$ : $53.4\left(\mathrm{COOCH}_{3}\right), 124.9$, 137.4, 137.5, 137.6, 137.8 (isoindole moiety), 170.1, 170.9, 171.2, 171.6, 172.1, 172.3 (peptide carbonyls), $173.8\left(\mathrm{COOCH}_{3}\right)$.

\subsubsection{Product 7}

Off-white powder. TLC $\left(\mathrm{CH}_{2} \mathrm{Cl}_{2}: \mathrm{MeOH}=9: 1\right)$ : 0.11. MALDI-TOF MS: $[\mathrm{M}+\mathrm{H}]^{+}=1439.2 \mathrm{~m} / \mathrm{z}$, calculated for $\mathrm{C}_{75} \mathrm{H}_{60} \mathrm{~N}_{8} \mathrm{O}_{19} \mathrm{~S}_{2}$ 1439.3; HRMS (ESI) $m / z$ found: $1439.3327[\mathrm{M}+\mathrm{H}]^{+}$, calculated: 1439.3332 $[\mathrm{M}+\mathrm{H}]^{+} ; \nu_{\max }(\mathrm{KBr}$ disc $) 3420,2927,1659,1575,1208 ;{ }^{1} \mathrm{H}$ NMR $\left(\mathrm{MeOH}-d_{4}, 500 \mathrm{MHz}\right) \delta: 3.84\left(\mathrm{COOCH}_{3}\right), 3.81\left(\mathrm{COOCH}_{3}\right), 4.13,4.53$, 4.80, 5.39, 5.40, 5.45, 5.78 (glycopeptides chiral $\mathrm{CH}$ ), 7.79, 7.82, 7.83, 7.96 (isoindole moiety), 7.96, 8.01 (benzothiazole moiety). ${ }^{13} \mathrm{C} \mathrm{NMR}$ $\left(\mathrm{MeOH}-d_{4}, 125 \mathrm{MHz}\right) \delta$ : $53.4\left(\mathrm{COOCH}_{3}\right), 121.2,126.6,132.8,150.9$, 163.1 (benzothiazole moiety), 124.5, 137.9, 138.2, 138.4 (isoindole moiety), 170.6, 171.1, 171.2, 171.3, 171.9, 172.3 (peptide carbonyls), $173.4\left(\mathrm{COOCH}_{3}\right)$.

\subsubsection{Product $\boldsymbol{8}$}

Off-white powder. TLC $\left(\mathrm{CH}_{2} \mathrm{Cl}_{2}: \mathrm{MeOH}=8: 2\right)$ : 0.67. MALDI-TOF MS: $[\mathrm{M}+\mathrm{Na}]^{+}=1406.4 \mathrm{~m} / \mathrm{z}$, calculated for $\mathrm{C}_{72} \mathrm{H}_{57} \mathrm{~N}_{9} \mathrm{O}_{19} \mathrm{SNa}$ 1406.4; HRMS (ESI) $m / z$ found: $1384.3560[\mathrm{M}+\mathrm{H}]^{+}$, calculated: $1384.3564[\mathrm{M}+\mathrm{H}]^{+} ; \nu_{\max }(\mathrm{KBr}$ disc) 3391, 2926, 1661, 1513, 1207; ${ }^{1} \mathrm{H}$ NMR $\left(\mathrm{MeOH}-d_{4}, 500 \mathrm{MHz}\right) \delta: 3.86\left(\mathrm{COOCH}_{3}\right), 3.81\left(\mathrm{COOCH}_{3}\right)$, 4.12, 4.49, 4.85, 5.35, 5.40, 5.46, 5.80 (glycopeptides chiral $\mathrm{CH}$ ), 7.82, 7.86, 8.02 (isoindole moiety), 8.03, 8.57, 8.60 (pyrimidyl moiety). ${ }^{13} \mathrm{C}$ NMR (MeOH- $\left.d_{4}, 125 \mathrm{MHz}\right) \delta$ : $53.4\left(\mathrm{COOCH}_{3}\right), 126.1,138.7,146.8$, 172.4 (pyrimidyl moiety), 125.6, 138.1, 138.6, 138.7 (isoindole moiety), $173.7\left(\mathrm{COOCH}_{3}\right)$.

\subsubsection{Product $\mathbf{9}$}

Pale brown powder. TLC (Tol:MeOH $=7: 3$ ): 0.30. MALDI-TOF MS: $[\mathrm{M}+\mathrm{Na}]^{+}=1454.5 \mathrm{~m} / \mathrm{z}$, calculated for $\mathrm{C}_{78} \mathrm{H}_{61} \mathrm{~N}_{7} \mathrm{O}_{19} \mathrm{SNa}$ 1454.4; HRMS (ESI) $\mathrm{m} / z$ found: $1432.3820[\mathrm{M}+\mathrm{H}]^{+}$, calculated: $1432.3816[\mathrm{M}+\mathrm{H}]^{+} ; \nu_{\max }(\mathrm{KBr}$ disc) 3387, 2932, 1657, 1510, 1207; ${ }^{1} \mathrm{H}$ NMR $\left(\mathrm{MeOH}-d_{4}, 500 \mathrm{MHz}\right) \delta: 3.81\left(\mathrm{COOCH}_{3}\right), 4.14,4.48,4.90$, 5.33, 5.39, 5.45, 5.79 (glycopeptides chiral $\mathrm{CH}$ ), 6.98, 7.04 (Ph-S), 7.17, 7.18, 7.20, 7.43, 8.35 (benzoisoindole moiety). ${ }^{13} \mathrm{C}$ NMR $\left(\mathrm{MeOH}-d_{4}, 500 \mathrm{MHz}\right) \delta: 53.4\left(\mathrm{COOCH}_{3}\right), 122.6,122.8,124.0,124.2$, 125.0, 126.4, 126.7 (benzoisoindole moiety), 135.9, $136.6(\mathrm{Ph}-\mathrm{S})$, $170.4,171.0,171.3,171.4,171.9,172.4$ (peptide carbonyls), 173.6 $\left(\mathrm{COOCH}_{3}\right)$.

\subsubsection{Product $\mathbf{1 0}$}

Pale brown powder. $\mathrm{TLC}\left(\mathrm{CH}_{2} \mathrm{Cl}_{2}: \mathrm{MeOH}=9: 1\right)$ : 0.23. MALDI-TOF MS: $[\mathrm{M}+\mathrm{K}]^{+}=1472.4 \mathrm{~m} / z$, calculated for $\mathrm{C}_{76} \mathrm{H}_{59} \mathrm{~N}_{9} \mathrm{O}_{19} \mathrm{SK}$ 1472.5; HRMS (ESI) $\mathrm{m} / z$ found: $1434.3729[\mathrm{M}+\mathrm{H}]^{+}$, calculated: 1434.3721 $[\mathrm{M}+\mathrm{H}]^{+} ; \nu_{\max }(\mathrm{KBr} \operatorname{disc}) 3384,2925,2856,1664,1508,1206 ;{ }^{1} \mathrm{H}$ NMR $\left(\mathrm{MeOH}-d_{4}, 125 \mathrm{MHz}\right) \delta: 3.88\left(\mathrm{COOCH}_{3}\right), 3.81\left(\mathrm{COOCH}_{3}\right), 4.13$, 4.50, 4.89, 5.37, 5.40, 5.43, 5.78 (glycopeptides chiral $\mathrm{CH}$ ), 7.36, 7.42,
7.43, 7.53, 8.04, 8.28 (benzoisoindole moiety), 7.97, 8.36 (pyrimidyl moiety). ${ }^{13} \mathrm{C}$ NMR $\left(\mathrm{MeOH}-d_{4}, 500 \mathrm{MHz}\right) \delta: 53.7\left(\mathrm{COOCH}_{3}\right), 131.6$, 147.8, 171.8 (pyrimidyl moiety), 114.2, 126.5, 130.6, 130.8, 131.2, 131.7 (benzoisoindole moiety), 170.5, 171.0, 171.2, 171.4, 172.0, 172.3 (peptide carbonyls), $173.8\left(\mathrm{COOCH}_{3}\right)$.

\section{Acknowledgements}

The work is supported by the TÁMOP 4.2.1/B-09/1/KONV-20100007 project. The project is co-financed by the European Union and the European Social Fund. The work was also supported by the Hungarian Research Fund OTKA through Grants K 79126, T-46186, K 101850, OTKA-NKTH CK 77515, and NK 68578. L.N. and E.V. acknowledge the technical assistance from Leentje Persoons and Wim van Dam, and the financial support from the Flemish Fonds voor Wetenschappelijk Onderzoek (FWO No. 9.0188.07) and the Geconcerteerde Onderzoeksacties (GOA/10/014).

\section{Appendix A. Supplementary information}

Supplementary data related to this article can be found at doi: 10.1016/j.ejmech.2012.10.030.

\section{References}

[1] a A. Malabarba, T.I. Nicas, R.S. Thompson, Med. Res. Rev. 17 (1997) 69-137; b S. Jovetic, Y. Zhu, G.L. Marcone, F. Marinelli, J. Tramper, Trends Biotechnol. 28 (2010) 596-604.

[2] a P.-A. Ashford, S.P. Bew, Chem. Soc. Rev. 41 (2012) 957-978; b H.C. Neu, Science 257 (1992) 1064-1073.

[3] K. Kristóf, E. Kocsis, D. Szabó, S. Kardos, V. Cser, K. Nagy, P. Hermann, F. Rozgonyi, Eur. J. Clin. Microbiol. Infect. Dis. 30 (2011) 691-699.

[4] W.E. Grundy, A.C. Sinclair, R.J. Theriault, A.W. Goldstein, C.J. Rickler, H.B. Warren, T.I. Oliver, J.C. Sylvester, Antibiot. Annu. (1956-1957) 687-692.

[5] J.L. Pace, G. Yang, Biochem. Pharmacol. 71 (2006) 968-980.

[6] E.J. Gangarosa, T.R. Johnson, H.S. Ramos, AMA Arch. Intern. Med. 105 (1960) 83-89.

[7] B. Bardsley, D.H. Williams, T.P. Baglin, Blood Coagul. Fibrinolysis 9 (1998) 241-244.

[8] R. Nagarajan, A.A. Schabel, J.L. Occolowitz, F.T. Counter, J.L. Ott, A.M. Felty-Duckworth, J. Antibiot. 42 (1998) 63-72.

[9] a K.C. Nicolaou, C.N.C. Boddy, S. Bräse, N. Winssinger, Angew. Chem. Int. Ed. 38 (1999) 2096-2152;

b D. Kahne, C. Leimkuhler, W. Lu, C. Walsh, Chem. Rev. 105 (2005) 425-448.

[10] F. Sztaricskai, G. Pintér, E. Röth, P. Herczegh, S. Kardos, F. Rozgonyi, Z. Boda, J. Antibiot. 60 (2007) 529-533.

[11] L. Naesens, E. Vanderlinden, E. Rőth, J. Jekő, G. Andrei, R. Snoeck, C. Panneconque, E. Illyés, G. Batta, P. Herczegh, F. Sztaricskai, Antivir. Res. 82 (2009) 84-89.

[12] G. Pintér, I. Bereczki, G. Batta, R. Ötvös, F. Sztaricskai, E. Rőth, E. Ostorházi, F. Rozgonyi, L. Naesens, M. Szarvas, Z. Boda, P. Herczegh, Bioorg. Med. Chem. Lett. 20 (2010) 2713-2717.

[13] G. Pintér, G. Batta, S. Kéki, A. Mándi, I. Komáromi, K. Takács-Novák F. Sztaricskai, E. Rőth, E. Ostorházi, F. Rozgonyi, L. Naesens, P. Herczegh, J. Med. Chem. 52 (2009) 6053-6061.

[14] a K. Palczewski, P.A. Hargrave, M. Kochman, Eur. J. Biochem. 137 (1983) 429-435; b P. Zuman, Chem. Rev. 104 (2004) 3217-3238.

[15] J. Wanner, D. Tang, C.C. McComas, B.M. Crowley, W. Jiang, J. Moss, D.L. Boger, Bioorg. Med. Chem. Lett. 13 (2003) 1169-1173.

[16] S.S. Simons, D.F. Johnson, J. Org. Chem. 43 (1978) 2886-2890.

[17] M.C. García Alvarez-Coque, M.J. Medina Hernández, R.M. Villanueva Camañas, C. Mongay Fernández, Anal. Biochem. 178 (1998) 1-7.

[18] www.acdlabs.com/resources/freeware/chemsketch/logp/.

[19] F. Joux, P. Lebaron, Microbes Infect. 2 (2000) 1523-1535.

[20] R. Hanczkó, A. Jámbor, A. Perl, I. Molnár-Perl, J. Chromatogr. A 1163 (2007) $25-42$.

[21] F. Sztaricskai, G. Batta, P. Herczegh, A. Balázs, J. Jekő, E. Rőth, P.T. Szabó, S. Kardos, F. Rozgonyi, Z. Boda, J. Antibiot. 59 (2006) 564-582.

[22] E. Vanderlinden, F. Göktas, Z. Cesur, M. Froeyen, M.L. Reed, C.J. Russell, N. Cesur, L. Naesens, J. Virol. 84 (2010) 4277-4288. 